\title{
Risk factors associated with neural tube defects in infants referred to western Iranian obstetrical centers; 2013-2014
}

\author{
Farzaneh Zaheri ${ }^{1}$, Fariba Ranaie ${ }^{2}$, Roonak Shahoei ${ }^{3}$, Leila Hasheminasab ${ }^{4}$, Daem Roshani ${ }^{5,6}$
}

${ }^{1}$ Lecturer, School of Nursing \& Midwifery, Kurdistan University of Medical Sciences (KUMS), Sanandaj, Iran

${ }^{2}$ Lecturer, School of Nursing \& Midwifery, Kurdistan University of Medical Sciences (KUMS), Sanandaj, Iran

${ }^{3}$ Associate Professor, School of Nursing \& Midwifery, Kurdistan University of Medical Sciences (KUMS), Sanandaj, Iran

${ }^{4}$ Lecturer, School of Nursing \& Midwifery, Kurdistan University of Medical Sciences (KUMS), Sanandaj, Iran

${ }^{5}$ Assistant Professor of Biostatistics, Social Determinants of Health Research Center, Kurdistan University of Medical Sciences, Sanandaj, Iran

${ }^{6}$ Assistant Professor of Biostatistics, Department of Epidemiology and Biostatistics, Medical School, Kurdistan University of Medical Sciences, Sanandaj, Iran

\section{Type of article: Original}

\begin{abstract}
Background: Neural tubes defects (NTDs) are known to be the second most prevalent congenital disorder worldwide whose risk factors have not been explicitly addressed yet.

Aim: To determine the risk factors affecting NTDs among infants who referred to obstetrical centers in Kurdistan, a western province of Iran.

Methods: This prospective case-control study was conducted in the form of prospective case-control. Sample population included all women (27,153 cases) who referred to obstetrical centers in Kurdistan for either delivery or abortion during 2013 and 2014. Inclusion criterion was the presence of a known NTD in infants, and exclusion criterion was the reluctance of patients to participate in the study. Accordingly, 46 cases participated in the study as the case group, and 138 cases (three times higher than case group) were selected to be the control group. Case and control groups were matched in terms of the number of pregnancies and place of birth. The variables investigated in the present study were as follows: age, occupation, BMI, abortion history, family relation with husband, fetus' sex, number of twins, history of previous children with NTD, receiving prenatal surveillance, consumption of folic acid and multivitamins, smoking, alcohol drinking, passive smoking, and suffering from such diseases as epilepsy and diabetes. Data were analyzed using various statistical tests, including chi-square, Fishers' exact test, multiple logistic regression analysis using SPSS version 20. In the study group, inclusion criteria included all women who had an infant with tube defects that their total number was 46 individuals. In the control group inclusion criteria included mothers with healthy infants who were similar to the study group in terms of birth place and frequency of pregnancy.

Results: The results of the present study demonstrated that prenatal surveillance $(p<0.002)$, multivitamin consumption $(p<0.001)$, history of having a child with NTD $(p<0.001)$, alcohol drinking $(p<0.014)$, and passive smoking were related to NTDs $(\mathrm{p}<0.001)$.

Conclusion: Before fertilization and during pregnancy, mothers should be examined in terms of exposure to harmful agents, diet, and nutritional status in order to identify possible risk factors and find opportunities to prevent NTDs in infants.
\end{abstract}

Keywords: Risk factor, Infant, abnormally, Neural tubes defect

\section{Corresponding author:}

Leila Hasheminasab, Kurdistan School of Nursing \& Midwifery, Pasdaran St, 66177-13446, Sanandaj, Iran.

Tel: +98-871-33664659 and +98-918-371-0634, Fax: +98-871- 6660092, email: Hasheminasab.1.2014@gmail.com Received: January 11, 2017, Accepted: April 22, 2017, Published: June 2017

iThenticate screening: April 07, 2017, English editing: May 27, 2017, Quality control: June 04, 2017

(C) 2017 The Authors. This is an open access article under the terms of the Creative Commons Attribution-NonCommercialNoDerivs License, which permits use and distribution in any medium, provided the original work is properly cited, the use is non-commercial and no modifications or adaptations are made. 


\section{Introduction}

NTDs refers to a group of severe congenital disorders caused by failure in closing the neural tube which mainly occurs during the first 28 days of pregnancy $(1,2)$. These abnormalities cause infants to die in the first year of their lives or in survived cases, have permanent disabilities $(3,4)$. Normally, one out of four fetuses with NTDs would be stillborn, and in $50 \%$ of cases an early abortion is expected. Other cases that survive, need various medical supports, including shunts for hydrocephalus, and orthopedic and urologic treatments (5). With age, the survived cases would encounter many problems, such as physical disabilities, bed sores, obesity, and heart diseases (6). The prevalence of NTDs has been reported to be one in a thousand births. However, the prevalence may differ in a range of 2 to 10 in a thousand births from one country to another (7). For example, the prevalence in the northern regions of India has been estimated to be 7.48 in a thousand births (8), while in northern Iran, it is about 25.4 in ten thousand births (4). Previous studies in various countries showed that environmental and genetic factors can contribute in the incidence of these disorders such as alcohol consumption, diet and nutritional status, social and economic condition, diseases like diabetes, infant gender, homozygous twins, drug abuse, smoking, passive smoking, and folic acid deficiency (917). The results of Talebian et al. study in 2015 in Kashan showed that the history of childbirth with neural tube defects, infant gender, maternal age, frequency of pregnancy, history of abortion in maternal diabetes, maternal folic acid intake, consanguinity, high maternal BMI and birth season are considerable risk factors for neural tube defects (18). Furthermore, there are many risk factors that have not been identified yet (19). Moreover, results of studies in this area are contradictory, however, it is evident that NTDs are multifactorial (20) and other factors such as geoecological environment (21), race, diet, and biologic factors (22) are said to affect NTDs. Until now there is no study in Kurdistan province in this regard. The identification of these factors can cause an increase in healthy newborns and a reduction in induced abortion.

\section{Material and Methods}

The present prospective case-control study was set to determine some risk factors believed to influence NTDs in Kurdistan during 2013-2014. The sample population consisted of all women (27,153 cases) who presented to obstetrical centers in Kurdistan province for either delivery or abortion. They were included as the case group if their birth or abortion date was between May 2013 and May 2014 and had at least one of the NTDs approved by sonography or neonatologist. Accordingly, 46 cases participated in the study as the case group and 138 cases (three times higher than the case group) were selected to be the control group. Case and control groups were matched in terms of number of pregnancies and place of birth. The only exclusion criterion was the reluctance of the mother to participate in the study, however, there was no such case. The required information was collected by interviewing the mothers, medical records, and a questionnaire. The validity and reliability of the questionnaire were assessed by the authors. The following variables are assessed in the present study; mother' $\mathrm{s}$ age in three groups (16-25, 26-35, and above 36 years), occupation of mother (housewife/employed), First trimester mothers' BMI (lower than 19.8, 19.8-26, 26/1-29.9, $\geqslant 30$ ), history of abortion (yes/no), fetus gender, family relation of mothers to their husbands (yes/no), history of having a previous baby with NTDs, number of twins, prenatal surveillance (regular surveillance/irregular surveillance), folic acid consumption in the time interval from one month before fertilization to one month after (yes/no), multivitamin consumption in the time interval from one month before fertilization to one month after (yes/no), suffering from diabetes or epilepsy during pregnancy (yes/no), smoking (none/lower than one/1-9/more than nine cigarettes), passive smoking (none/lower than one hour/1-4 hours/higher than four hours per day), alcohol consumption (none/once per month/2-3 times per month/4-5 times per month/more than 5 times per months). Fisher's exact test and chi-square tests were used to analyze the data. Factors with a probability lower than 0.2 were introduced to the multiple logistic regression model and analyzed at various levels. SPSS version 20 used for performing statistical tests. Data were analyzed using SPSS software (version 20) and Fisher Exact S and chisquare tests were used to determine the relationship between studied factors and incidence of tube defects. Various studied factors included taking a multivitamin, folic acid intake, alcohol consumption, smoking, exposure to secondhand smoke, maternal disease, prenatal care and history of child birth with NTDs. All cases were analyzed using multivariate logistic regression model at difference levels with a probability value of less than 2.0 (at the significant level of $\mathrm{p}<0.05$ and confidence interval of $95 \%$ ). The study was approved by the ethical committee of the Kurdistan University of Medical Sciences.

\section{Results}

According to the results of the present study, most cases had age ranges of $16-25$ years $(60.9 \%)$, likewise, 53.6\% of women of the control group belonged to this age group (Table 1). Of cases that had a history of abortion, there was $10.9 \%$ of the case group and $13 \%$ of the control group. In terms of BMI, most mothers of the case group were in the 25-29.9 range, while in the control group, most mothers were in the 19.6-24.9 range, however, the difference was 
not significant ( $\mathrm{p}=0.95$ ). There was $28.3 \%$ of the case group and $15.9 \%$ of the control group which suffered from either diabetes or epilepsy during their pregnancy period. Furthermore $78.3 \%$ of the case group and $94.9 \%$ of the control group had received regular surveillance during their pregnancy period, however, they were significantly different in terms of this variable $(\mathrm{p}<0.002)$. Moreover, in the present study, only $15.2 \%$ of the case group and $25.4 \%$ of the control group consumed folic acid in the time interval \pm 1 month of fertilization and the difference between the two groups was not significant ( $\mathrm{p}=0.11$ ). In addition, $60.8 \%$ of the case group and $90.6 \%$ of the control group received multivitamins within a month time interval before and after fertilization. The difference of the two groups in terms of this variable was significant ( $<<0.001$ ). Likewise, $6.5 \%$ of the case group and $3.6 \%$ of the control group had a history of a previous child with NTDs, and the difference between the two groups was significant, as well $(p<0.003)$, whereas, the two groups were significantly different in terms of alcohol consumption and passive smoking in a confided space $(\mathrm{p}<0.014)$. Multivariate logistic regression model showed that the history of previous infant with NTDs (CI=0.095 and 1.75-68.94) $\mathrm{OR}=10.94$-alcohol consumption in the month before and after pregnancy, $(\mathrm{CI}=95 \%, 1.15-173.03), \mathrm{OR}=14.13$ and exposure to cigarette smoke $(\mathrm{CI}=0.095$ and 1.44-8.31), $\mathrm{OR}=3.44$ are associated $(\mathrm{p}<0.001)$ with the incidence of NTDs in infants (Table 2$)$.

Table 1. The prevalence of NTD with respect to demographic and midwifery of the case and control groups

\begin{tabular}{|c|c|c|c|c|}
\hline \multicolumn{2}{|l|}{ Characteristics } & \multicolumn{2}{|l|}{ Groups } & \multirow[t]{2}{*}{ p-value } \\
\hline & & \multirow{3}{*}{$\begin{array}{l}\text { Case; } n \\
(\%) \\
28(60.9)\end{array}$} & \multirow{2}{*}{$\begin{array}{l}\text { Control; n } \\
(\%) \\
74(53.6)\end{array}$} & \\
\hline \multirow[t]{3}{*}{ Mother's age (year) } & $16-25$ & & & \multirow[t]{3}{*}{$0.26 \dagger$} \\
\hline & $26-35$ & & $42(30.4)$ & \\
\hline & $36<$ & $3(6.5)$ & $22(15.9)$ & \\
\hline \multirow[t]{2}{*}{ History of abortion } & Yes & $5(10.9)$ & $18(13)$ & \multirow[t]{2}{*}{$0.46^{*}$} \\
\hline & No & $\begin{array}{l}41(89.1 \\
5)\end{array}$ & $120(87)$ & \\
\hline \multirow[t]{2}{*}{ Fetus gender } & Female & $25(54.3)$ & $71(51.5)$ & \multirow[t]{2}{*}{$0.43 *$} \\
\hline & Male & $21(45.7)$ & 67 (48.5) & \\
\hline \multirow[t]{4}{*}{ BMI $\left(\mathrm{kg} / \mathrm{m}^{2}\right)$} & $<19.8$ & $5(10.9)$ & $8(5.8)$ & \multirow[t]{4}{*}{$0.95 \dagger$} \\
\hline & $19.8-26$ & $14(30.4)$ & $58(42)$ & \\
\hline & $26.1-29.9$ & $21(45.7)$ & $53(38.4)$ & \\
\hline & $\geq 30$ & $6(13)$ & $19(13.8)$ & \\
\hline \multirow[t]{2}{*}{ Mother's job } & Employed & $3(6.5)$ & $8(5.8)$ & \multirow[t]{2}{*}{$0.54 *$} \\
\hline & Housewife & $43(93.5)$ & $130(94.2)$ & \\
\hline \multirow[t]{2}{*}{ Mother's disease } & Yes & $13(28.3)$ & $22(15.9)$ & \multirow[t]{2}{*}{$0.06^{*}$} \\
\hline & No & $33(71.7)$ & $116(84.1)$ & \\
\hline \multirow[t]{2}{*}{ Prenatal surveillance } & Yes (regular) & $36(78.3)$ & $131(94.9)$ & \multirow[t]{2}{*}{$0.002 *$} \\
\hline & No (irregular) & $10(21.7)$ & $7(5.1)$ & \\
\hline \multirow{2}{*}{$\begin{array}{l}\text { Folic acid consumption from one month before to the end } \\
\text { of the first month of pregnancy }\end{array}$} & Yes & $7(15.2)$ & $35(25.4)$ & \multirow[t]{2}{*}{$0.11 *$} \\
\hline & No & $39(84.8)$ & $103(74.6)$ & \\
\hline \multirow{2}{*}{$\begin{array}{l}\text { Multivitamin consumption from one month before to the } \\
\text { end of the first month of pregnancy }\end{array}$} & Yes & $28(60.8)$ & $125(90.6)$ & \multirow[t]{2}{*}{$0.001 *$} \\
\hline & No & $18(39.2)$ & $13(9.4)$ & \\
\hline \multirow[t]{2}{*}{ NTDs history in previous children } & Yes & $3(6.5)$ & $5(3.6)$ & \multirow[t]{2}{*}{$<0.003^{*}$} \\
\hline & No & $43(93.5)$ & $133(96.4)$ & \\
\hline \multirow[t]{2}{*}{ Family relation to husband } & Yes & $9(19.6)$ & $24(17.4)$ & \multirow[t]{2}{*}{$0.44^{*}$} \\
\hline & No & $37(17.4)$ & $114(82.6)$ & \\
\hline \multirow{2}{*}{$\begin{array}{l}\text { Alcohol consumption from one month before to the end } \\
\text { of the first month of pregnancy }\end{array}$} & No & $42(91.3)$ & $133(96.4)$ & \multirow[t]{2}{*}{$0.014 *$} \\
\hline & $\begin{array}{l}2-3 \text { times per } \\
\text { month }\end{array}$ & $4(8.7)$ & $1(7)$ & \\
\hline \multirow[t]{2}{*}{$\begin{array}{l}\text { Smoking from one month before to the end of the first } \\
\text { month of pregnancy }\end{array}$} & $\begin{array}{l}\text { 1-9 cigarettes } \\
\text { per day }\end{array}$ & $4(8.7)$ & $4(2.9)$ & $0.1^{*}$ \\
\hline & No & $42(91.3)$ & $134(97.1)$ & \\
\hline $\begin{array}{l}\text { Passive smoking from one month before to the end of the } \\
\text { first month of pregnancy }\end{array}$ & $\begin{array}{l}1-4 \text { hours per } \\
\text { day }\end{array}$ & $24(52.2)$ & $36(26.1)$ & $0.001 *$ \\
\hline & No & $22(47.8)$ & $102(73.9)$ & \\
\hline
\end{tabular}

*Fisher's exact test; $\uparrow$ Chi-square test 
Table 2. Logistic regression Analysis of Association between Risk Factors and NTDs

\begin{tabular}{|c|c|c|c|c|c|c|}
\hline \multirow{2}{*}{\multicolumn{2}{|c|}{ Characteristics }} & \multirow[t]{2}{*}{$\begin{array}{l}\text { Case; } n \\
(\%)\end{array}$} & \multirow[t]{2}{*}{$\begin{array}{l}\text { Control; } \mathrm{n} \\
(\%)\end{array}$} & \multirow[t]{2}{*}{$\begin{array}{l}\mathrm{p}- \\
\text { value }\end{array}$} & \multicolumn{2}{|c|}{$\begin{array}{l}\text { Logistic } \\
\text { regression }\end{array}$} \\
\hline & & & & & Beta & OR \\
\hline \multirow[t]{2}{*}{ Prenatal surveillance } & Yes (regular) & $36(78.3)$ & $131(94.9)$ & \multirow[t]{2}{*}{0.04} & \multirow[t]{2}{*}{-0.021} & \multirow[t]{2}{*}{0.41} \\
\hline & No (irregular) & $10(21.7)$ & $7(5.1)$ & & & \\
\hline \multirow{2}{*}{$\begin{array}{l}\text { Folic acid consumption from one month } \\
\text { before to the end of the first month of } \\
\text { pregnancy }\end{array}$} & Yes & $7(15.2)$ & $35(25.4)$ & \multirow[t]{2}{*}{0.649} & \multirow[t]{2}{*}{0.316} & \multirow[t]{2}{*}{1.37} \\
\hline & No & $39(84.8)$ & $103(74.6)$ & & & \\
\hline \multirow{2}{*}{$\begin{array}{l}\text { Multivitamin from one month before to the } \\
\text { end of the first month of pregnancy }\end{array}$} & Yes & $28(60.8)$ & $125(90.6)$ & \multirow[t]{2}{*}{0.001} & \multirow[t]{2}{*}{-0.039} & \multirow[t]{2}{*}{0.14} \\
\hline & No & $18(39.2)$ & $13(9.4)$ & & & \\
\hline \multirow[t]{2}{*}{ NTDs history in previous children } & Yes & $3(6.5)$ & $5(3.6)$ & \multirow[t]{2}{*}{0.011} & \multirow[t]{2}{*}{4.19} & \multirow[t]{2}{*}{10.94} \\
\hline & No & $43(93.5)$ & $133(96.4)$ & & & \\
\hline \multirow{2}{*}{$\begin{array}{l}\text { Alcohol consumption from one month } \\
\text { before to the end of the first month of } \\
\text { pregnancy }\end{array}$} & No & $42(91.3)$ & $133(96.4)$ & \multirow[t]{2}{*}{0.038} & \multirow[t]{2}{*}{6.25} & \multirow[t]{2}{*}{14.13} \\
\hline & $\begin{array}{l}\text { 2-3 times per } \\
\text { month }\end{array}$ & $4(8.7)$ & $1(7)$ & & & \\
\hline \multirow[t]{2}{*}{$\begin{array}{l}\text { Passive smoking from one month before to } \\
\text { the end of the first month of pregnancy }\end{array}$} & $\begin{array}{l}1-4 \text { hours per } \\
\text { day }\end{array}$ & $24(52.2)$ & $36(26.1)$ & \multirow[t]{2}{*}{0.005} & \multirow[t]{2}{*}{0.049} & \multirow[t]{2}{*}{3.44} \\
\hline & no & $22(47.8)$ & $102(73.9)$ & & & \\
\hline \multirow[t]{2}{*}{ Mother's disease } & Yes & $13(28.3)$ & $22(15.9)$ & \multirow[t]{2}{*}{0.758} & \multirow[t]{2}{*}{0.157} & \multirow[t]{2}{*}{1.17} \\
\hline & No & $33(71.7)$ & $116(84.1)$ & & & \\
\hline \multirow[t]{2}{*}{$\begin{array}{l}\text { Smoking from one month before to the end } \\
\text { of the first month of pregnancy }\end{array}$} & $\begin{array}{l}1-9 \text { cigarettes } \\
\text { per day }\end{array}$ & $4(8.7)$ & $4(2.9)$ & \multirow[t]{2}{*}{0.694} & \multirow[t]{2}{*}{0.364} & \multirow[t]{2}{*}{1.4} \\
\hline & No & $42(91.3)$ & $134(97.1)$ & & & \\
\hline
\end{tabular}

\section{Discussion}

According to the results of the present study, the lack of regular prenatal surveillance can increase the risk of NTDs in infants. Jahangiri and Nili demonstrated that inadequate surveillance can be a major risk factor of NTDs in infants (23) and also related to other major abnormalities in children (24). Prenatal surveillance can create opportunities for identifying nutrients deficiencies, and other factors may increase the risk of NTDs (25). One of the most important issues that should be taken into account during the period before and after fertilization is the consumption of folic acid, which has been known as a strong factor in preventing NTDs $(19,20)$. In the present study, although we did not find a significant relationship between folic acid consumption the dietary differences in terms of amount of intake of foods that increase the blood level of acid, folic such as milk, fresh vegetables, and fruits played a key role on the incidence of NTDs, (26). Furthermore, fortification of wheat flour with folic acid can be very useful in this regard (15). The results of our study also emphasized that multivitamin consumption in the time interval of a month before and after fertilization had a preventive effect against developing NTDs, Therefore, there is another influential substance rather than folic acid in multivitamin that is helpful in preventing NTDs. This difference may be due to the lack of measurement of serum vitamin B12 and other micronutrients, which can be considered as one of the limitations in the present study and can be investigated in future studies. Regarding this finding, some studies mentioned that B12 vitamin had preventive effects against NTDs (27-29), whereas, there are also other studies, that found no relationship between these two $(16,29)$. Chandler et al. (30) in their study in 2012 found that consumption of micronutrients such as iron, vitamin C, vitamin E, thiamin, and retinol can reduce the risk of NTDs. Lack of data associated with serum level of B12 and other micronutrients of mothers was one of the limitations of the present study that should be addressed by future studies. Furthermore, the results of the present study demonstrated that the risk of NTDs increases among women who have had an infant with the same disorder, which is in line with previous studies $(31,32)$. Normally, 2 to $5 \%$ of the general population have a history of infants with NTDs $(33)$. However, Talebian et al. showed that there was no association between family history and NTD (18). A 50 times higher risk of NTDs in children that have a sister or brother with NTDs, the increase of the risk after having two or three babies, and a higher risk in twins with the same sex are all evidences that convince us to consider the genetic factor as a contributory factor in NTDs (7). According to the results of the present study, alcohol drinking increased the risk of NTDs. There are some other studies that reported the same results, as well, e.g. (34),, whereas some other studies reported no significant association between these two $(29,31)$. However, it should be noted that some participants did not tend to express the truth about this variable because of social considerations. Biological mechanisms for explaining the effect of alcohol on fetus evolution is not available. However, studies conducted on animals have 
demonstrated that in the first periods of fetus evolution, alcohol kills many neural crest cells (35). The results of the present study showed that passive smoking of mothers increased the risk of NTDs in infants, which is in line with previous studies (36-38). However, Benedum et al. did not report a significant association between these two (39). Carbon monoxide presented in smoke, prevents oxygen from reaching fetus tissues by forming carboxyhemoglobin (40). From fertilization to birth, ovum, embryos, and then fetuses should be adopted to the surrounding environment and changes within their own cells. During fertilization, it depends on the nutritional status of maternal and paternal germ cells, and after that, it depends on nutritional status, metabolisms, and life style of the mother. Nutrients consumed by the mother are the main source of all necessary elements needed for the fetus for transcription of growth factors and cell signaling during its growth and development (41). NTDs are multifactorial (9), and the present study indicates that many environmental, genetic, and nutritional factors have an influence on these types of disorders. NTD incidence is more likely in the case of alcohol consumption than other factors. Moreover, taking care during pregnancy has a key role in preventing NTD incidence due to decreased risk factors. The present study has several strong points; all cases with the final outcome of pregnancy, either successful delivery or abortion, were included and investigated in the study, the study was prospective and covered all obstetrical centers located in Kurdistan province. All participants were always available which helped us to gather more precise information, so there was no limitation about forgetting information or misunderstanding questionnaire questions.

\section{Conclusions}

Results indicated that the risk of NTD increased with alcohol use, exposure to secondhand smoke and the history of childbirth with NTD, while, its risk decreased with getting regular prenatal care and taking multivitamins. The results can be useful in reducing the risk factors of these disorders. Genetic counseling is recommended before pregnancy in women with a history of previous childbirth with NTD. Examination and training about the conditions and high-risk behavior of mothers' pre-pregnancy advice should be performed with greater attention.

\section{Acknowledgments:}

The authors would like to thank Kurdistan University of Medical Sciences for financial support. The authors also thank all participants and staff of the obstetrical centers for their collaboration.

\section{Conflict of Interest:}

There is no conflict of interest to be declared.

\section{Authors' contributions:}

All authors contributed to this project and article equally. All authors read and approved the final manuscript.

\section{References:}

1) Onrat ST, Seyman H, Konuk M. Incidence of neural tube defects in Afyonkarahisar, Western Turkey. Genet Mol Res. 2009; 8(1): 154-61. PMID: 19283682.

2) Seidahmed MZ, Abdelbasit OB, Shaheed MM, Alhussein KA, Miqdad AM, Khalil MI, et al. Epidemiology of neural tube defects. Saudi Med J. 2014; 35 Suppl 1: S29-35. PMID: 25551108, PMCID: PMC4362102.

3) Flores A, Vellozzi C, Valencia D, Sniezek J. Global burden of neural tube defects, risk factors, and prevention. Indian J Community Health. 2014; 26(Suppl 1): 3-5. PMID: 26120254, PMCID: PMC4480200.

4) Wilde JJ, Petersen JR, Niswander L. Genetic, epigenetic, and environmental contributions to neural tube closure. Annu Rev Genet. 2014; 48: 583-611. doi: 10.1146/annurev-genet-120213-092208. PMID: 25292356, PMCID: PMC4649936.

5) Mandıracioğlu A, Ulman I, Lüleci E, Ulman C. The incidence and risk factors of neural tube defects in Izmir, Turkey: a nested case-control study. Turk J Pediatr. 2004; 46(3): 214-20. PMID: 15503473.

6) Loo KW, Gan SH. Folic acid supplementation is not the sole factor in determining neural tube defects: The possible role of autoantibodies. African Journal of Biotechnology. 2012; 11(55): 11767-71. doi: 10.5897/AJB12.065.

7) Copp AJ, Stanier P, Greene ND. Neural tube defects: recent advances, unsolved questions, and controversies. The Lancet Neurology. 2013; 12(8): 799-810. doi: 10.1016/S1474-4422(13)70110-8. PMID: 23790957, PMCID: PMC4023229.

8) Rai SK, Singh R, Pandey S, Singh K, Shinde N, Rai S, et al. High incidence of neural tube defects in Northern part of India. Asian J Neurosurg. 2016; 11(4): 352-5. PMID: 27695536 , PMCID: PMC4974957.

9) De Marco P, Merello E, Cama A, Kibar Z, Capra V. Human neural tube defects: Genetic causes and prevention. Biofactors. 2011; 37(4): 261-8. doi: 10.1002/biof.170. PMID: 21674647. 
10) Carmichael SL, Yang W, Feldkamp ML, Munger RG, Siega-Riz AM, Botto LD, et al. Reduced risks of neural tube defects and orofacial clefts with higher diet quality. Arch Pediatr Adolesc Med. 2012; 166(2): 121-6. doi: 10.1001/archpediatrics.2011.185. PMID: 21969361, PMCID: PMC3973484.

11) Yang J, Carmichael SL, Canfield M, Song J, Shaw GM. Socioeconomic status in relation to selected birth defects in a large multicentered US case-control study. Am J Epidemiol. 2008; 167(2): 145-54. doi: 10.1093/aje/kwm283. PMID: 17947220.

12) Salih MA, Murshid WR, Seidahmed MZ. Classification, clinical features, and genetics of neural tube defects. Saudi Med J. 2014; 35 Suppl 1: S5-S14. PMID: 25551113, PMCID: PMC4362100.

13) Yerby MS. Clinical care of pregnant women with epilepsy: neural tube defects and folic acid supplementation. Epilepsia. 2003; 44 Suppl 3: 33-40. doi: 10.1046/j.1528-1157.2003.t01-1-44703.x-i1. PMID: 12790884.

14) Nauman N, Jalali SS, AslamShami S, Akhtar N. Consanguinity and Neural Tube Defects. Journal of Rawalpindi Medical College. 2016; 20(2): 120-3.

15) Golalipour MJ, Qorbani M, Mirfazeli A, Mobasheri E. Risk factors of neural tube defects in northern iran. Iran Red Crescent Med J. 2014; 16(6): e7940. doi: 10.5812/ircmj.7940. PMID: 25068063, PMCID: PMC4102996.

16) Suarez L, Felkner M, Brender JD, Canfield M, Hendricks K. Maternal exposures to cigarette smoke, alcohol, and street drugs and neural tube defect occurrence in offspring. Matern Child Health J. 2008; 12(3): 394-401. doi: 10.1007/s10995-007-0251-y. PMID: 17641961.

17) Salmasi G, Grady R, Jones J, McDonald SD. Environmental tobacco smoke exposure and perinatal outcomes: a systematic review and meta-analyses. Acta Obstet Gynecol Scand. 2010; 89(4): 423-41. doi: 10.3109/00016340903505748. PMID: 20085532.

18) Talebian A, Soltani B, Sehat M, Zahedi A, Noorian A, Talebian M. Incidence and Risk Factors of Neural Tube Defects in Kashan, Central Iran. Iran J Child Neurol. 2015; 9(3): 50-6. PMID: 26401153, PMCID: PMC4577698.

19) Al Rakaf MS, Kurdi AM, Ammari AN, Al Hashem AM, Shoukri MM, Garne E, et al. Patterns of folic acid use in pregnant Saudi women and prevalence of neural tube defects - Results from a nested case-control study. Prev Med Rep. 2015; 2: 572-6. doi: 10.1016/j.pmedr.2015.06.016. PMID: 26844119, PMCID: PMC4721389.

20) Safi J, Joyeux L, Chalouhi G. Periconceptional folate deficiency and implications in neural tube defects. J Pregnancy. 2012; 2012: 295083. doi: 10.1155/2012/295083. PMID: 22900183, PMCID: PMC3415073.

21) Golalipour M, Vakili M, Arya B. Neural tube defects in newborns in the south-east of the Caspian sea border (Gorgan, Iran 1998-2000). Med J Islam Repub Iran. 2003; 16(4): 199-203.

22) Mobasheri E, Keshtkar A, Golalipour MJ. Maternal folate and vitamin B12 status and neural tube defects in Northern Iran: a case control study. Iran J Pediatr. 2010; 20(2): 167-73. PMID: 23056699, PMCID: PMC3446032.

23) Nili F, Jahangiri M. Risk factors for neural tube defects: a study at university-affiliated hospitals in Tehran. Arch Iran Med. 2006; 9(1): 20-5. PMID: 16649373.

24) Shahnazi M, Azeri S. Contributing Factors in Major Malformations in Neonatals Born in Alzahra MedicalEducational Hospital, Tabriz. Journal of Nursing and Midwifery, Tabriz. 2010; 18: 49-56.

25) Tong VT, Dietz PM, Rolle IV, Kennedy SM, Thomas W, England LJ. Clinical interventions to reduce secondhand smoke exposure among pregnant women: a systematic review. Tob Control. 2015; 24(3): 21723. doi: 10.1136/tobaccocontrol-2013-051200. PMID: 24789602, PMCID: PMC4924528.

26) Wang M, Wang ZP, Gao LJ, Yang H, Zhao ZT. Maternal consumption of non-staple food in the first trimester and risk of neural tube defects in offspring. Nutrients. 2015; 7(5): 3067-77. doi: 10.3390/nu7053067. PMID: 25919306, PMCID: PMC4446739.

27) Molloy AM, Kirke PN, Troendle JF, Burke H, Sutton M, Brody LC, et al. Maternal vitamin B12 status and risk of neural tube defects in a population with high neural tube defect prevalence and no folic acid fortification. Pediatrics. 2009; 123(3): 917-23. doi: 10.1542/peds.2008-1173. PMID: 19255021, PMCID: PMC4161975.

28) Thompson MD, Cole DE, Ray JG. Vitamin B-12 and neural tube defects: the Canadian experience. Am J Clin Nutr. 2009; 89(2): 697S-701S. doi: 10.3945/ajcn.2008.26947B. PMID: 19116334.

29) Zhang T, Xin R, Gu X, Wang F, Pei L, Lin L, et al. Maternal serum vitamin B12, folate and homocysteine and the risk of neural tube defects in the offspring in a high-risk area of China. Public Health Nutr. 2009; 12(05): 680-6. doi: 10.1017/S1368980008002735. PMID: 18547453. 
30) Chandler AL, Hobbs CA, Mosley BS, Berry RJ, Canfield MA, Qi YP, et al. Neural tube defects and maternal intake of micronutrients related to one - carbon metabolism or antioxidant activity. Birth Defects Res A Clin Mol Teratol. 2012; 94(11): 864-74. doi: 10.1002/bdra.23068. PMID: 22933447, PMCID: PMC3518275.

31) Afshar M, Kiyanfar S. The incidence of NTD in newborns and related risk factors in Birjand, 1996-2000. Journal of Gorgan University of Medical Sciences. J Gorgan Uni Med Sci. 2004; 6(2): 45-51.

32) Gu X, Lin L, Zheng X, Zhang T, Song X, Wang J, et al. High prevalence of NTDs in Shanxi Province: a combined epidemiological approach. Birth Defects Res A Clin Mol Teratol. 2007; 79(10): 702-7. doi: 10.1002/bdra.20397. PMID: 17729293.

33) Deak KL, Siegel DG, George TM, Gregory S, Ashley - Koch A, Speer MC. Further evidence for a maternal genetic effect and a sex - influenced effect contributing to risk for human neural tube defects. Birth Defects Res A Clin Mol Teratol. 2008; 82(10): 662-9. doi: 10.1002/bdra.20511. PMID: 18937341, PMCID: PMC2981339.

34) Grewal J, Carmichael SL, Ma C, Lammer EJ, Shaw GM. Maternal periconceptional smoking and alcohol consumption and risk for select congenital anomalies. Birth Defects Res A Clin Mol Teratol. 2008; 82(7): 519-26. doi: 10.1002/bdra.20461. PMID: 18481814, PMCID: PMC2861577.

35) Bannigan J, Burke P. Ethanol teratogenicity in mice: a light microscopic study. Teratology. 1982; 26(3): 247-54. doi: 10.1002/tera.1420260305. PMID: 7163973.

36) Li ZW, Liu JM, Ren AG, Zhang L, Guo ZY, Li Z. [Maternal passive smoking and the risk of neural tube defects: a case-control study in Shanxi province, China]. Zhonghua Liu Xing Bing Xue Za Zhi. 2008; 29(5): 417-20. PMID: 18956669.

37) Suarez L, Ramadhani T, Felkner M, Canfield MA, Brender JD, Romitti PA, et al. Maternal smoking, passive tobacco smoke, and neural tube defects. Birth Defects Res A Clin Mol Teratol. 2011; 91(1): 29-33 .doi: 10.1002/bdra.20743. PMID: 21254356.

38) Wang M, Wang ZP, Zhang M, Zhao ZT. Maternal passive smoking during pregnancy and neural tube defects in offspring: a meta-analysis. Arch Gynecol Obstet. 2014; 289(3): 513-21. doi: 10.1007/s00404013-2997-3. PMID: 23942772.

39) Benedum CM, Yazdy MM, Mitchell AA, Werler MM. Risk of spina bifida and maternal cigarette, alcohol, and coffee use during the first month of pregnancy. Int J Environ Res Public Health. 2013; 10(8): 3263-81. doi: 10.3390/ijerph10083263. PMID: 23917813, PMCID: PMC3774437.

40) Viljoen E. Harmful effects of smoking in pregnancy. S Afr Med J. 2008; 95(5): 329-30. PMID: 15931445.

41) Dolk H, Committee EPM. What is the "primary" prevention of congenital anomalies? The Lancet. 2009; 374(9687): 378. doi: 10.1016/S0140-6736(09)61411-2. 